\title{
Phytochemical Investigation and Antimicrobial Activity of Six Plants Used in Children's Ailments Treatment in Niger
}

\author{
Mahamane Idi Issa Abdoulahii, *, Bakasso Sahabi ${ }^{1}$, Alio Sanda Abdelkader ${ }^{2}$, \\ Ilagouma Amadou Tidjani', Yaou Chaïbou ${ }^{4}$, Moctar Chaibou ${ }^{1}$, Adamou Ibrahim Maman Laouali ${ }^{2}$, \\ Kiendrebeogo Martin ${ }^{3}$, Sadou Hassimi ${ }^{4}$ \\ ${ }^{1}$ Department of Chemistry, Faculty of Science and Technology, Abdou Moumouni University, Niamey, Niger \\ ${ }^{2}$ Departement of Biology, Faculty of Science and Technology, Abdou Moumouni University, Niamey, Niger \\ ${ }^{3}$ Life and Earth Sciences Training And Research Unit, Faculty of Science and Technology, University of Ouagadougou, Ouagadougou, \\ Burkina Faso \\ ${ }^{4}$ Department of Chemistry, Faculty of Science and Technology, Abdou Moumouni University, Niamey, Niger
}

Email address:

m_abdoulahi@yahoo.com (M. I. I. Abdoulahi),b_sahabi2000@yahoo.fr (B. Sahabi), aliosanda@yahoo.fr (A. S. Abdelkader), ilagoumat@mail.com (I. A. Tidjani),martinkiendreeogo@yahoo.co.uk (K. Martin), hassimi@yahoo.com (S. Hassimi)

${ }^{*}$ Corresponding author

\section{To cite this article:}

Mahamane Idi Issa Abdoulahi, Bakasso Sahabi, Alio Sanda Abdelkader, Ilagouma Amadou Tidjani, Yaou Chaïbou, Moctar Chaibou, Adamou Ibrahim Maman Laouali, Kiendrebeogo Martin, Sadou Hassimi. Phytochemical Investigation and Antimicrobial Activity of Six Plants Used in Children's Ailments Treatment in Niger. Journal of Diseases and Medicinal Plants. Vol. 6, No. 4, 2020, pp. 92-97.

doi: $10.11648 /$ j.jdmp.20200604.15

Received: December 8, 2020; Accepted: December 16, 2020; Published: December 31, 2020

\begin{abstract}
Resistance phenomena of infectious agents to synthesis drugs and the high cost of these drugs led to medicinal plants as an alternative against infectious disease. The objective of this study is to characterize different classes of secondary metabolites and to test the antibacterial activity of six plants: Bauhinia rufescens Lam, Blepharis linariifolia PERS, Chrozophora brocchiana Vis, Gardenia ternifolia Schum and Thonn, Indigofera astragalina DC, Phyllanthus pentandrus Schumach \&Thonn, used in traditional medicine for children treatment. The extracts are obtained by aqueous decoction with the 1/10 model (50 g of each sample in $500 \mathrm{ml}$ of solvent). Phytochemical screening of these six plants was carried out by standards tests, which are reactions of colorations, precipitation and complexation. The agr medium diffusion was used for the sensitivity test of the aqueous extracts of these plants against two strains of bacteria (two isolates of Salmonella typhimurium lettuce and clinical). Phytochemical screening showed the presence of polyphenols, tannins, flavonoids, coumarins, alkaloids, sterols/triterpenes in all tested extracts. All extracts contain saponins except Phyllanthus pentandrus. For free quinones, only Phyllanthus pentandrus and Indigofera astragalina showed a negative test. Among these six plants, five (5) showed an activity on Salmonella typhimurium at $200 \mathrm{mg} / \mathrm{mL}$. C. brocchiana and P. pentandrus showed the best activity on $S$. typhimurium (lettuce) with $19.5 \pm 0.70 \mathrm{~mm}$ and $17.5 \pm 0.70 \mathrm{~mm}$, respectively. At the concentration of $50 \mathrm{mg} / \mathrm{mL}$, only these two plants are also showed antibacterial activity on $S$. typhimurium (lettuce). The results obtained indicate that these plants contain some secondary metabolites, some have antimiocrobial activity and constitute a scientific database for the research in the field of phytomedicines. These results will justify the use of these plants in the treatment of some infections.
\end{abstract}

Keywords: Phytochemistry, Salmonella typhimurium, Infectious Agents, Niger

\section{Introduction}

Infectious diseases are a public health problem because of their frequency and severity. Salmonella is one of infectious agents, present in food and our environment. The distribution analysis of annual number of Salmonella gastroenteritis cases estimates that 93.757 .000 cases of which causes 155,000 deaths [1]. In Niger, isolated Salmonella prevalence from foods is very high. The prevalence of Salmonella found in lettuce in Niger is $36.94 \%$ and $38.06 \%$ from poultry [2, 3]. 
The discovery of antibiotics was a real relief to humanity because this class of drugs has helped in reducing the damage caused by infectious diseases, especially in developed countries. But the misuse of these drugs has led to the development of resistance in infectious agents. Moreover, a multi-resistance to the antibiotic of isolated Salmonella strains in human and in food have been proved [4]. Conventional medicines generally have undesirable effects and are expensive.

Considering the constantly high cost of available drugs, associated with the emergence of multi-resistant pathogens, the African Pharmacopoeia has been recognized [5, 6]. In Africa, up to $80 \%$ of the population uses traditional medicine to manage their health [7]. Plants are generally presented as having efficacy; they are low cost and available.

The aim of the present study is to characterize the different classes of secondary metabolites extract from the six plants which are commonly used in Niger in the management of child care and to evaluate the antibacterial activity on two strains of Salmonella.

\section{Material and Methods}

\subsection{Plant Material}

The study samples are made up of: Bauhinia rufescens Lam (leaves), Indigofera astragalina DC (whole plant), Phyllanthus pentandrus Schumach \& Thonn (whole plant), Chrozophora brocchiana Vis (whole plant), Blepharis linariifolia PERS (whole plant without seeds) and Gardenia ternifolia Schum and Thonn (fruits) (Figure 1). After identification of plants species, samples were washed and then left to dry in a ventilated room at room temperature. They were then crushed using a mechanical grinder and the resulting grind (powder) was stored in a dry place, away from moisture and light.

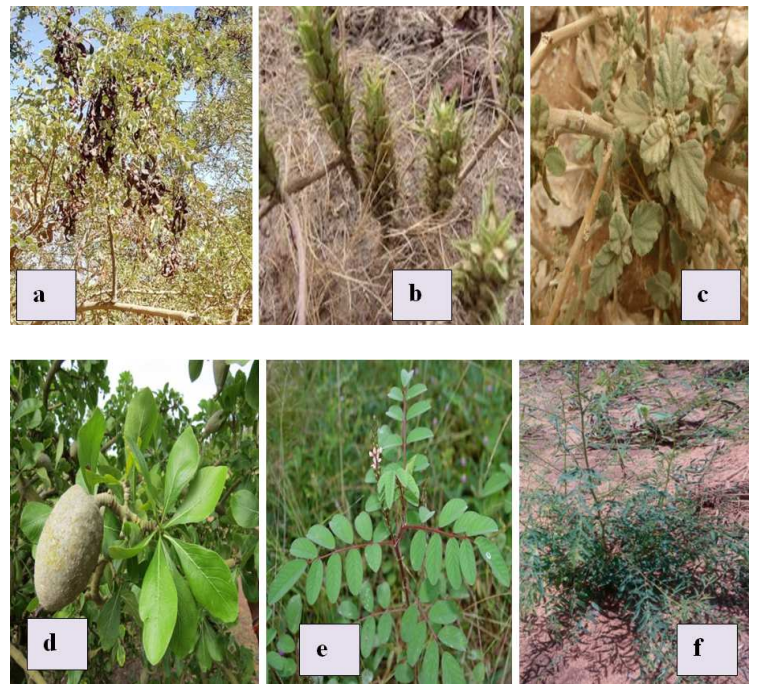

Figure 1. (a) B. rufescens; (b) B. linariifolia; (c) C. brocchiana; (d) G. ternifolia; (e) I. astragalina; (f) P. pentandrus.

\subsection{Biological Material}

Two isolates of Salmonella typhimurium was used to test the activity of these plants. One isolated from lettuce (lettuce) and another from patients at the national hospital of Niamey (clinical strain). The bacteria were cultured on Muller-Hinton agar at $37^{\circ} \mathrm{C}$.

\subsection{Extraction}

The $50 \mathrm{~g}$ of powder obtained from each plant was placed in a one-litre flask containing $500 \mathrm{~mL}$ of distilled water. The mixture is heated at $60^{\circ} \mathrm{C}$ for 1 hour. After cooling, the mixture is filtered in a beaker using a funnel and filter paper. The sand bath is used to evaporate the water in order to obtain a dry extract.

\subsection{Phytochemical Tests}

Phytochemical screening is carried out by tube reactions according to techniques described by Ciulei in 1982; Wagner and Bladt in 1996 with some modifications [8, 9].

1. Tannins have been identified by Stiasny's reagent.

2. Polyphenols have been identified by the $\mathrm{FeCl}_{3}$ test.

3. Flavonoids by the cyanidin reaction.

4. Saponosides by the foam test.

5. Coumarins by the $\mathrm{NH}_{4} \mathrm{OH}$ and observation under the UV lamp at $366 \mathrm{~nm}$.

6. Quinones by the Bornträger test.

7. Triterpenes and the steroids by the LiebermannBurchard test.

8. Alkaloids by the Mayer, Dragendorf tests and Wagner.

\subsection{Determination of Antibacterial Activity}

\subsubsection{Preparation of Culture Medium}

The medium used in this study is Agar Muller Hinton (MH) obtained by dissolving $38 \mathrm{~g}$ of $\mathrm{MH}$ medium in $1 \mathrm{~L}$ of distilled water ( $\mathrm{pH} 7.5 \pm 0.2$ ). This medium was autoclaved at $121^{\circ} \mathrm{C}$ for $15 \mathrm{~min}$.

\subsubsection{Disc Method for Sensitivity Testing}

After sterilization, Muller Hinton Agar (MH) was poured into Petri dishes (diameter $90 \mathrm{~mm}$ ). For each bacterial strain, a bacterial suspension of 0.5 Mac Ferland turbidity was prepared using physiological water. The bacterial inoculum was swabbed and inoculated into plate agar by spreading. Discs of blotting sheets, diameter $6 \mathrm{~mm}$, previously impregnated with $25 \mu \mathrm{L}$ of each extract of plant to be tested (200 $\mathrm{mg} / \mathrm{mL}$ and $50 \mathrm{mg} / \mathrm{mL}$ ) and antibiotics (positive control) were placed on the sterile plates agar. The discs were prepared 24 hours before the test and incubated at $37^{\circ} \mathrm{C}$. The positive control used was Ciprofloxacin $(2 \mathrm{mg} / \mathrm{mL})$. The DMSO 25\% was used as negative control. The inoculated plate agar was incubated at $37^{\circ} \mathrm{C}$ for 24 hours. The antibacterial activity was determined by measuring the diameter of the inhibition zone induced by the extracts or antibiotics. Extracts or antibiotics that have induced an inhibition zone over than three diameters $(>3 \mathrm{~mm})$ around the disc are considered to have antibacterial activity. Each test was repeated 3 times in a row [10-12]. 


\subsection{Data Analysis}

All data were analyzed using Excel to calculate means, standard deviations and obtain the graph and correlations. The analysis of variance (ANOVA) from the XLSTAT software was used to measure the statistical difference.

\section{Results and Discussion}

\subsection{Extraction Yield of Six Plant Samples}

Distilled water was used as solvent. The best yield is observed with Bauhinia rufescens and Phyllanthus pentandrus. The other four plants gave more or less low yields (Figure 2).

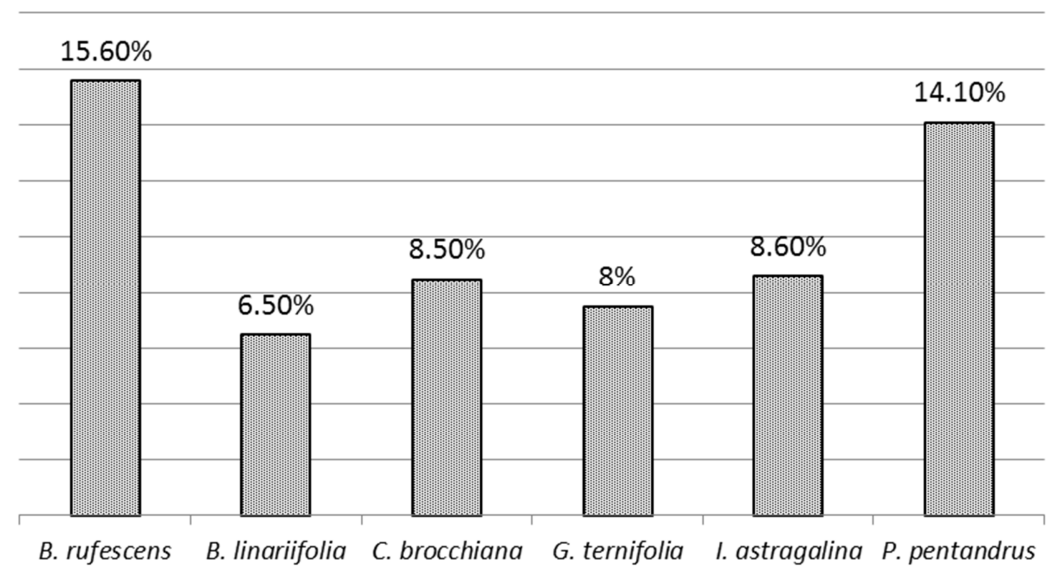

Figure 2. Extraction yield of aqueous extracts.

\subsection{Phytochemical Screening}

The results of the phytochemical screening of six plant samples are reported in Table 1.

Table 1. Results of phytochemical screening of six plant samples.

\begin{tabular}{|c|c|c|c|c|c|c|c|c|c|c|c|}
\hline \multirow{2}{*}{ Species } & \multirow{2}{*}{ Family } & \multirow{2}{*}{ Organ (s) } & \multicolumn{2}{|c|}{ Alc } & \multirow{2}{*}{ Tan } & \multirow{2}{*}{ Flv } & \multirow{2}{*}{ Sap } & \multirow{2}{*}{ Quin } & \multirow{2}{*}{ Ter/str } & \multirow{2}{*}{ Poly } & \multirow{2}{*}{ Cou } \\
\hline & & & D & M & & & & & & & \\
\hline B. rufescens & Fabaceae & Le & + & - & + & + & + & + & + & + & + \\
\hline B. linariifolia & Acanthaceae & Wps & - & - & + & + & + & + & + & + & + \\
\hline C. brocchiana & Euphorbiaceae & $\mathrm{Wp}$ & + & - & + & + & + & + & + & + & + \\
\hline G. ternifolia & Rubiaceae & $\mathrm{Fr}$ & + & - & + & + & + & + & + & + & + \\
\hline I. astragalina & Fabaceae & $\mathrm{Wp}$ & + & + & + & + & + & - & + & + & + \\
\hline P. pentandrus & Euphorbiaceae & $\mathrm{Wp}$ & - & - & + & + & - & - & + & + & + \\
\hline
\end{tabular}

Alc=alkaloids; Tan=tannins; Flv=flavonoids; Sap=saponins; Quin=quinone; Ter/str=terpene/sterol; Poly=polyphenols; Cou=coumarin; absence=-; presence=+; $\mathrm{Wp}=$ Whole plant; $\mathrm{Fr}=$ fruit; $\mathrm{Le}=$ leaves; $\mathrm{Wps}=$ Whole plant without seeds $\mathrm{D}=$ Dragendorff; $\mathrm{M}=$ Mayer.

Phytochemical screening revealed the presence of tannins and flavonoids in all extracts of plants. The phytochemical screening of $B$. rufescens performed by Aliyu et al. (2009) on the methanolic extract of leaves showed the presence of flavonoids, tannins, alkaloids, triterpenes and saponins [13]; these results are similar to those obtained in the present study but with the aqueous extract. This could be explained by the fact that methanol and water are polar solvents. The study carried out by Yolidjé et al. (2019) on Chrozophora brocchiana aqueous and methanolic extracts showed the presence of flavonoids, tannins, saponins, sterols and polyterpenes in the aqueous extract [14]. However, the presence of coumarins and quinones is observed. Some work has also shown an absence of alkaloids in the aqueous and ethanol extracts of this plant $[15,16]$.

The phytochemical screening of the aqueous extract of Gardenia ternifolia, showed the presence of the groups sought. Kallo et al. (2018), found flavonoids, tannins and alkaloids in the aqueous extract [17].

For the plant $I$. astragalina, the results of the present study are the same as those found by Yolidjé et al. (2019), which showed the presence of flavonoids, tannins, alkaloids and sterols/polyterpenes in the aqueous extract [14].

Their high use and efficiency reported by Bilan et al. (2018) could be explained by the fact that these plants simultaneously contain these two groups of secondary metabolites (tannins and flavonoids) [18]. Tannins have antidiarrheal properties and are enzyme inhibitors and flavonoids have anti-inflammatory properties [19]. The synergistic action between antidiarrheal, anti-inflammatory properties and the inhibition of the development of certain microorganisms is a primordial importance in the fight against certain diseases [19].

The phytochemical study also showed the presence of other groups of secondary metabolites (sterols/triterpenes, quinones and saponins) which may also be very important for 
the proper functioning of the human body. The different groups of secondary metabolites detected, could justify the use and possible interesting biological activities which could intervene in the treatment of some affections of the children.

\subsection{Antibacterial Activity}

The results of the sensitivity test are recorded in the Table 2.

Table 2. Diameter of inhibition of the development of bacteria ( $\mathrm{mm}$ ).

\begin{tabular}{|c|c|c|c|}
\hline \multirow{2}{*}{ Strains } & \multirow{2}{*}{ Plants / witnesses } & \multicolumn{2}{|c|}{ Inhibition diameter } \\
\hline & & $200 \mathrm{mg} / \mathrm{ml}$ & $50 \mathrm{mg} / \mathrm{ml}$ \\
\hline \multirow{8}{*}{ S. Typhimurium (lettuce) } & Ciprofloxacin $(2 \mathrm{mg} / \mathrm{mL})$ & $23,5 \pm 0,70 \mathrm{a}$ & $23,5 \pm 0,70 \mathrm{a}$ \\
\hline & C. brocchiana & $19,5 \pm 0,70 b$ & $10 \pm 1,41 b$ \\
\hline & P. pentandrus & $17,5 \pm 0,70 \mathrm{~b}$ & $9 \pm 2,82 b$ \\
\hline & B. linariifolia & $13,5 \pm 2,12 \mathrm{c}$ & $0 \mathrm{c}$ \\
\hline & B. rufescens & $12 \pm 0,70 \mathrm{c}$ & $0 \mathrm{c}$ \\
\hline & I. astragalina & $9,5 \pm 0,70 \mathrm{~cd}$ & $0 \mathrm{c}$ \\
\hline & G. ternifolia & $0 \mathrm{e}$ & $0 \mathrm{c}$ \\
\hline & Negative control & $0 \mathrm{e}$ & $0 \mathrm{c}$ \\
\hline \multirow{8}{*}{ S. Typhimurium (clinical) } & Ciprofloxacin $(2 \mathrm{mg} / \mathrm{mL})$ & $23,5 \pm 0,70 \mathrm{a}$ & $23,5 \pm 0,70 \mathrm{a}$ \\
\hline & B. linariifolia & $7,5 \pm 0,70 \mathrm{c}$ & $0 \mathrm{~b}$ \\
\hline & B. rufescens & $0 \mathrm{~d}$ & $0 \mathrm{~b}$ \\
\hline & C. brocchiana & $8,5 \pm 0,70 \mathrm{c}$ & $0 \mathrm{~b}$ \\
\hline & G. ternifolia & $0 \mathrm{~d}$ & $0 \mathrm{~b}$ \\
\hline & I. astragalina & $0 \mathrm{~d}$ & $0 \mathrm{~b}$ \\
\hline & P. pentandrus & $11,5 \pm 0,70 b$ & $0 \mathrm{~b}$ \\
\hline & Negative control & $0 \mathrm{~d}$ & $0 \mathrm{~b}$ \\
\hline
\end{tabular}

Values are means \pm standard deviation of three determinations (zone of inhibition in mm). Columns with different letters (a, b, $\mathrm{c}$, d, and e) indicate statistical differences $(P<0.05)$.

These results of antimicrobial test appeared to be statistically different $(\mathrm{p}<0.05)$ from plant to plant and variation of concentration.

No inhibition zones were found around the disc impregnated with 25\% DMSO (Figure 3c). For $S$. typhimurium isolated from lettuce, five (5) plants showed activity at $200 \mathrm{mg} / \mathrm{mL}$ and the diameter ranged from $9.5 \pm 0.70 \mathrm{~mm}$ to $19.5 \pm 0.70 \mathrm{~mm}$. The $23.5 \pm 0.70 \mathrm{~mm}$ were obtained with Ciprofloxacin (Figure $3 \mathrm{c}$ ). The C. brocchiana and $P$. pentandrus were the plants which showed the highest antimicrobial activity on $S$. typhimurium (lettuce) with $19.5 \pm 0.70$ and $17.5 \pm 0.70 \mathrm{~mm}$ diameter respectively (Figure $3 \mathrm{a}$ and $3 \mathrm{~b}$ ). On $S$. typhimurium (clinical), three (3) plants, $P$. pentandrus, $C$. brocchiana and $B$. linariifolia, showed activity with diameters of $11.5 \pm 0.70 \mathrm{~mm}, 8.5 \pm 0.70 \mathrm{~mm}$ and $7.5 \pm 0.70 \mathrm{~mm}$, respectively. G. ternifolia showed no activity. These results indicate that the inhibition zones varied from strain to strain and extract to extract; thus, the clinical strain was more resistant than the strain isolated from lettuce. The statistical analyses show that the diameters of inhibition zones exhibited by S. Typhimurium (lettuce) was found to be significantly different $(\mathrm{p}<0.05)$ between all extracts of plants with Ciprofloxacin (CIP). However, insignificant different $(\mathrm{p}<0.05)$ was noted between the extracts of $C$. brocchiana and $P$. pentandrus. The diameters of inhibition zones from the extracts of $B$. linariifolia, B. rufescens and $I$. astragalina are not statistically different.

On S. Typhimurium (clinical) plants extracts are statistically different with Ciprofloxacin (CIP). Thus, the extracts of $C$. brocchiana and $B$. linariifolia are not statistically different though significantly different with the extracts of $P$. pentandrus.

The study carried out by Mahamane et al. (2020) on the same type of extract of these plants showed that $C$. brocchiana and $P$. pentandrus are the plants which contain more flavonoids with values of $51,60 \pm 0,28$ and $47,68 \pm 0,63$ $\mathrm{mg} \mathrm{QE} / \mathrm{g}$ (milligram quercetin equivalent per gramme) respectively [20]. The low content of flavonoids was obtained with the extract of $G$. ternifolia. The results of the determination of total polyphenols shows that $C$. brocchiana and $P$. pentandrus are the plants which contain more total polyphenols with values of $260.05 \pm 0.07$ and $256.08 \pm 1.07 \mathrm{mg}$ $\mathrm{GAE} / \mathrm{g}$ (milligram gallic acid equivalent per gram) respectively. The low content of total polyphenols was obtained with the extract of G. ternifolia [20].

The results of this study are in agreement with those of the study carried out by Odeyemi et al. (2014) in which showed that leaf, flowers and roots extracts of Tithonia diversifolia have antibacterial activities due to the presence of polyphenols [21]. Bruneton (1999) have shown that bacterial growth decreases with the lowering of the concentration of flavonoid fractions the anti-bacterial activity of flowering heads of Origanum glandulosum [22]

Phyllanthus pentandrus extract showed antibacterial activity against strains of $S$. Typhimurium (Lettuce) and $S$. Typhimurium (Clinical). Our results corroborate with those found by Alio [12].

Some authors show that the anti-salmonella activity is linked to the polyphenolic compounds. According to the study conducted by Bolou et al. (2011), the antibacterial activity of the AcOEt fraction of Terminalia glaucescens Planch on Salmonella typhi and Salmonella typhimurium is based on the presence of triterpenoids, polyphenols, quinones and alkaloids [23]. But for Javanmardi et al. (2002), the antibacterial activity of plant extracts would be attributed to secondary metabolites such as polyphenols and triterpenoids 
[24]. In the study carried out by Akomoun et al. (2019), they shown that phenolics and flavonoid compounds are responsible for the anti-salmonella activity of certains plants; they deduce that the flavonoids could be responsible for the anti-Salmonella activity of the roots of Zanthoxylum zanthoxyloides and the leaves of Momordica charantia [25].

It has been shown that the mechanism of toxicity of flavonoids to microorganisms is either by deprivation of metal ions such as iron, or by non-specific interactions such as the establishment of hydrogen bridges with the proteins of the cell walls of microorganisms (adhesins) or enzymes [26].

Phytochemical screening showed the presence of polyphenols in all six aqueous extracts, $G$. ternifolia contains polyphenols with no antimicrobial activity. Antimicrobial activity does not only depend on the presence of phenolic compounds, but also on the presence of other secondary metabolites [27]. Flavonoids have antifungal and antibacterial properties. In addition to these groups, there is also the group of quinones and derivatives that possess antimicrobial properties.

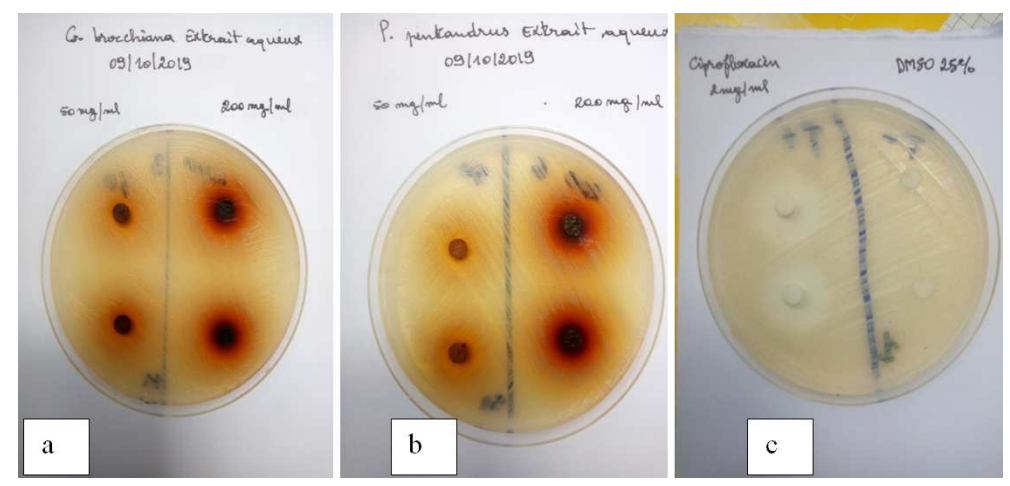

Figure 3. Some results on the diameter of inhibition of the development of bacteria from plant extracts (a and b) and controls (c).

\section{Conclusion}

This study has shown the presence of an important class of secondary metabolites that could justify the traditional use of these plants. Phytochemical screening revealed the presence of secondary metabolites: polyphenols, flavonoids, tannins, coumarins, alkaloids, saponins, quinones, sterols and terpenes. C. brocchiana and P. pentandrus have been shown the best antibacterial activity against the two strains used. The antimicrobial activity tested would justify the therapeutic use of these plants in traditional medicine in cases of bacterial infections caused by $S$. typhimurium. It is important in the next studies to determine minimum inhibitory concentrations (MIC), minimum bactericidal concentrations (MBC) and test the extract from these plants on other bacterial strains. Other work must also be carried out in order to prove the safety of these plants and carry out a bioguided fractionation in order to isolate the molecules responsibles for these activities.

\section{References}

[1] Shannon E. Majowicz, Jennie Musto, Elaine Scallan, Frederick J. Angulo, Martyn Kirk, Sarah J. O'Brien, Timothy F. Jones, Aamir Fazil, and Robert M. Hoekstra. (2010). for the International Collaboration on Enteric Disease 'Burden of Illness' Studies: The Global Burden of Nontyphoidal Salmonella Gastroenteritis Clinical Infectious Diseases; 50: pp 882-889.

[2] Alio Sanda A, Inoussa Maman M, Samna Soumana O, Bakasso Y. (2017). Diversité et dynamique des Salmonella isolées de la laitue (Lactuca sativa L.) dans les cultures maraîchères au Niger (Afrique de l'ouest). Journal of Applied
Biosciences 119: 11917-11928. ISSN 1997-5902.

[3] Alio Sanda Abdelkader, Samna Soumana Oumarou, Inoussa Maman Maârouhi, Soumana Abdou Boubacar, Moussa Hassane Ousseini, Bakasso Yacoubou. (2019). Diversity and Distribution of Salmonella Isolated from Poultry Offal in Niger (West Africa) International Journal of Microbiology and Biotechnology.

[4] Alio Sanda A, Samna Soumana O, Bakasso Y. (2018). Epidemiology, diversity and resistance to antibiotics in Salmonella strains isolated from human in two cities of Niger Republic. International Journal of Current Research, (IJCR) Vol. 10, Issue, 02, pp. 65364-65370, February, 2018.

[5] Konan KF, Guessennd KN, Oussou KR, Bahi C, Coulibaly A, Djaman AJ, DOSSO M. (2013). Effet antibactérien de l'extrait aqueux de l'écorce de Terminalia glaucescens Planch ex Benth (Combretaceae) sur la croissance in vitro des entérobactéries productrices de bêtalactamases à spectre élargi (EBLSE). Int. J. Biol. Chem. Sci., 8 (3): 1192-1201.

[6] Kouadio N. J., Guessennd N. K., Kone M. W., Moussa B., Koffy. M I, Guede K. B., Yao K., Bakayoko A., Trabi H. F. Et Dosso M. (2015). Evaluation de l'activité des feuilles de Mallotus oppositifolius (Geisel.) Müll.-Arg (Euphorbiaceae) sur des bactéries multirésistantes et criblage phytochimique. Int. J. Biol. Chem. Sci. 9 (3): 1252-1262, June 2015. ISSN 1997-342X (Online), ISSN 1991-8631. Available online at http://ajol.info/index.php/ijbcs.

[7] OMS, (2008). Statistique sanitaires mondiale 2008. (S. 1.): World Health Organization.

[8] Ciulei I. (1982). Pratical manuals on the industrialisation of medicinal and aromatic plants I. Methodology for analysis of vegetable drugs. Ministry of chemical industry, Bucherest, ROMANIA, p 67.

[9] Wagner H., Bladt S. (1996). Plant drug analysis A. thin layer chromatography. Atlas. Second Edition Springer 384pages. 
[10] Cos P., Vlietinck A. J.; Vanden Berghe D., Maes L. (2006). Anti-infective potential of natural products: How to develop a stronger in vitro 'proof-of-concept'. Journal of Ethnopharmacology, 106, 290-302.

[11] Bakasso S, (2009). Etudes phytochimiques et potentialités biologiques de cinq espèces d'Indigofera (Fabaceae) utilisées en médecine traditionnelle au Burkina Faso, Thèse Unique, Biochimie et chimie des substances naturelles. Université de Ouagadougou, Burkina Faso. 135 p.

[12] Alio Sanda Abdel Kader, Inoussa Maman Maârouhi, Samna Soumana Oumarou, Alfa Keita Djibo, Halima Oumarou Diadié, Mahamane Idi Issa Abdoulahi and Bakasso Yacoubou. (2020). Evaluation of antibacterial activity from extract of three plant species on strains of salmonella in niger. World Journal of Pharmacy and Pharmaceutical Sciences, Volume 9, Issue 3, 462-481, ISSN 2278-4357.

[13] Aliyu A. B., Ibrahim M. A., Musa A. M., Ibrahim H., Abdulkadir I. E. and Oyewale A. O., (2009). Evaluation of antioxydant activity of leave extract of Bauhinia rufescens Lam. (Caesalpiniaceae). Journal of Medicinal Plants Research Vol. 3 (8), (2009), pp. 563-567.

[14] Yolidjé I., Keita D. A., Moussa I., Toumane A., Maarouhi I. M., Saley K., Jean-Luc P, T. Much, Ouamba J. M. (2019). Caractérisation Phytochimique et Activité Larvicide d'extraits Bruts de Plantes Issues de la Pharmacopée Traditionnelle du Niger sur les Larves d'Anopheles gambiae S. L. European Scientific Journal April 2019 edition Vol. 15, No. 12 ISSN: 1857 - 7881 (Print) e - ISSN 1857-7431.

[15] Hima R. M., (2014). Etude des propriétés antibactériennes de deux plantes médicinales utilisées au Niger pour traiter les infections microbiennes. Mémoire de master, Université de Ouagadougou, Biotechnologie Microbienne et Cellulaire 61 p.

[16] Nassirou R. S., Ibrahim M. L., Ilagouma A. T., Mahamadou A., Mamoudou M., Abdoulaye A., Oukem-Boyer O. O. M. et Khalid I., (2015), Évaluation in vitro de l'activité antiplasmodiale d'extraits de plantes issues de la pharmacopée traditionnelle du Niger, Journal of Applied Biosciences 89: 8291-8300, ISSN 1997-5902.

[17] Kallo M. S., Adamou R., Sawadogo J., Mahamane A. A., Maarouhi I. M. et Khalid I. (2018). Enquête ethnobotanique et criblage phytochimique de quelques plantes tinctoriales du Niger en vue d'une valorisation en énergie solaire. Int. J. Biol. Chem. Sci. 12 (2): 867-883, ISSN 1997-342X (Online), ISSN 1991-8631, Available online at http://www.ifgdg.org.

[18] Bilan O. S., Ilagouma A. T., Nassirou R. S., Moussa I., Hamo I. (2018). Enquête ethnobotanique et screening chimique des plantes utilisées comme fortifiants pour nourrisson au Niger. Annales de l'Université Abdou Moumouni, Série A - Tome XXIV pp. 125-133, déc. 2018.

[19] Bruneton J., (2016). Pharmacognosie phytochimie-plantes médicinales; $5^{\mathrm{e}}$ édition@2016, Lavoisier, Paris; ISBN: 978-27430-2165-8; 1487 pages.

[20] Mahamane IDI ISSA Abdoulahi, Bakasso Sahabi, Hama Garba Rahila, Hama Hamadou Habibou, Hassane Hamidou Zeinabou, Ilagouma Amadou Tidjani, Martin Kiendrebeogo and Hassimi Sadou. (2020). Phenolics contents and antioxidant activity of six medicinal plants used in the treatment of dentition related ailments in Niger. Journal of Pharmacognosy and Phytochemistry 2020; 9 (4): 1816-1821.

[21] Odeyemi S. O. A. T., Agidigbi T. S., Adefemi S. O3. and Fasuan, (2014). Antibacterial activities of crude extracts of tithonia diversifolia against common environmental pathogenic bacteria, Internationl journal of science and technology The Experiment, vol. 20, no. 4, pp. 1421-1426.

[22] Bruneton J (1999) Pharmacognsie. Photochimie, plantes médicinales. Ed Lavoisier, 1120 p.

[23] Bolou G. E. K, Attioua B., N'guessan A. C., Coulibaly A., N'guessan J. D. Et Djaman A. J. (2011). Évaluation in vitro de l'activité antibactérienne des extraits de Terminalia glaucescens Planch. sur Salmonella typhi et Salmonella typhimurium. Bulletin de la Société Royale des Sciences de Liège, Vol. 80, 2011, p. 772-790.

[24] Javanmardi J., Khalighi A., Bais H. P. And Vivanco J. M., (2002), Chemical characterization of basil (Osmium basilium L.) found in local occasion and used in traditional medicine in Iran, Journal of Agricultural and food chemistry, 50, p. 5878 5883.

[25] Akomoun Blandine KAKPO, Eléonore YAYI, Bruno N. LENTA, Fidèle M. ASSOGBA, Placide M. TOCLO, Fabrice Fekam BOYOM, Lamine BABA-MOUSSA, and Joachim GBENOU (2019) Phytochemistry and anti-bacterial activity of thirteen plants used in traditional medicine to treat typhoid fever in Benin International Journal of Innovation and Applied Studies ISSN 2028-9324 Vol. 25 No. 3 Feb. 2019, pp. 10341047.

[26] Raj NK, Spiral RM, Chaluvadi MR, Krishna DR. (2001) Bioflavonoids classification, pharmacological, biochemical effects and therapeutic potential. Indian J Pharmacol 33: 2-16.

[27] Kil H. Y., Seong E. S., Ghimire B. K., Chung I. M., Kwon S. S., Goh E. J., Heo, K., Kim., M. J., Lim J. D., Lee D., Yu C. Y. (2009). Antioxidant and antimicrobial activities of crude sorghum extract. Food Chemistry. 115: 1234-1239. 